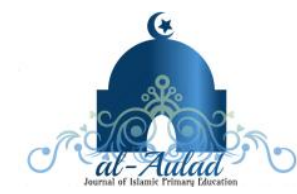

\title{
PENERAPAN ACADEMIC CONTROVERSY DALAM MENINGKATKAN AKTIVITAS BELAJAR
}

\author{
Arif Hidayat ${ }^{1}$ \\ ${ }^{\prime}$ MI At-Taqwa, Arcamanik, Kota Bandung, Indonesia \\ Arifh4718cipa@gmail.com
}

Naskah diterima: 1 Desember, 2018, direvisi: 29 Januari, 2019, diterbitkan: 31 Maret, 2019

\begin{abstract}
The purpose of this study is to find out student learning activities before applying the Academic Controversy method, then the learning process using the Academic Controversy method, and student learning activities after applying the Academic Controversy method on social studies subjects in each cycle. The method used in this study is Classroom Action Research (CAR) which consists of four stages repeatedly, namely planning, action, observation and reflection. The technique of collecting data was carried out through the evaluation instruments of the pro and contra debates then with observation sheets for student and teacher activities. Based on the results of the study, the percentage of student learning activities before being applied to the academic controversy (academic controversy) method was only $31.2 \%$ with the less active category, after the application of the academic controversy (academic controversy) method in the first cycle student learning activities increased to $62 \%$ included in the category is quite active. And student learning activities continue to increase in the second cycle which is at a very active stage which is $86 \%$. From these data it can be concluded that the application of the method of academic controversy (academic controversy) can increase learning activities.
\end{abstract}

Keywords: Academic Controversy, Islamic Elementary School, Learning Activities. Social Studies Learning.

\begin{abstract}
ABSTRAK
Tujuan penelitian ini untuk mengetahui aktivitas belajar siswa sebelum diterapkan metode Academic Controversy, lalu proses pembelajaran dengan menggunakan metode Academic Controversy, dan aktivitas belajar siswa setelah diterapkan metode Academic Controversy pada mata pelajaran IPS di setiap siklus. Metode yang digunakan dalam penelitian ini adalah Penelitian Tindakan Kelas (PTK) yang terdiri dari empat tahapan secara berulang, yaitu perencanaan, tindakan, observasi dan refleksi. Teknik pengumpulan data dilakukan melalui instrumen penilaian debat pro dan kontra kemudian dengan lembar observasi aktivitas siswa dan guru. Berdasarkan hasil penelitian menunjukan presentase aktivitas belajar siswa sebelum diterapkan metode struktur kontroversi akademik (controversy academic) hanya sebesar 31,2\%.dengan kategori kurang aktif, setelah penerapan metode struktur kontroversi akademik (controversy academic) pada siklus I aktivitas belajar siswa mengalami peningkatan menjadi $62 \%$ yang termasuk pada kategori cukup aktif. Dan aktivitas belajar siswa terus mengalami peningkatan pada siklus II yang berada pada tahap sangat aktif yaitu 86\%. Dari data tersebut dapat disimpulkan bahwa dengan penerapan metode struktur kontroversi akademik (controversy academic) dapat meningkatkan aktivitas belajar.
\end{abstract}

Kata Kunci: Academic Controversy, Aktivitas Belajar, Madrasah Ibtidaiyah, Pembelajaran IPS.

\section{PENDAHULUAN}

Adanya perubahan paragdigma pendidikan saat ini menuntut dilakukannya perubahan proses pembelajaran di kelas, peran guru saat ini diarahkan untuk menjadi fasilitator yang dapat membantu siswa dalam belajar, bukan sekedar penyampaian materi saja. Guru harus mampu mengikut sertakan siswa dalam kegiatan pembelajaran secara maksimal 
(Ruswandi, 2008). Pembelajaran akan lebih bermakna jika siswa diberi kesempatan untuk ikut serta dalam berbagai aktivitas kegiatan pembelajaran, sehingga siswa bisa menyalurkan bakatnya di dalam maupun diluar kelas. Begitupun apa bila kita ingin memperluas pengetahuan mengenai bagaimana cara mengelola pembelajaran di dalam kelas, maka kita harus bisa membedakan dan mengenali sumber reverensi yang diberikan, metode penelitian, dan cara kita merencanakan serta mengelola program akademik (Bacon, 2016).

Berkaitan dengan ini, karakteristik anak yang akan merasakan langsung pengalaman belajar sebagai satu kesatuan yang tidak bisa dipisahkan. Pelaksanaan pembelajaran harus dirancang secara tepat karena akan mempengaruhi terhadap kebermaknaan pengalaman pembelajar anak. Pengalaman belajar yang menunjukkan kaitan unsur-unsur konseptual baik di dalam maupun antar matapelajaran, akan memberi peluang bagi terjadinya pembelajaran yang efektif dan lebih bermakna (Rusman, 2013).

Pembelajaran mencerminkan perubahan dari waktu ke waktu, bukan keadaan pada saat tertentu. Istilah pembelajaran mengacu pada keuntungan pengetahuan yang dimiliki oleh siswa, umumnya didasarkan pada beberapa refleksi dan introspeksi. Istilah pembelajaran aktual membedakan pembelajaran nyata dari pembelajaran yang dirasakan. Pembelajaran aktual mencerminkan perubahan pengetahuan yang diidentifikasi oleh pengukuran pembelajaran yang ketat menawarkan bukti yang menarik mengenai perbedaan antara pembelajaran aktual dan konstruksi pembelajaran yang dirasakan (Bacon, 2016).

Menurut Trianto (2014) bahwa melalui pembelajaran terpadu, peserta didik dapat memperoleh pengalaman langsung sehingga dapat menambah kekuatan untuk menerima, menyimpan, dan menerapkan konsep yang telah dipelajarinya. Dengan demikian peserta didik terlatih untuk dapat menemukan sendiri berbagai konsep yang dipelajari secara menyeluruh (holistis), bermakna, autentik, dan aktif sehingga dapat mencapai tujuan program pendidikan sekolah dasar. Pendapat ini diperkuat bahwasanya penggunaan pembelajaran terpadu siswa diharapkan mempunyai kemampuan mengenai mengidentifikasi, mengumpulkan, menilai serta menggunakan informasi yang ada di sekitarnya secara bermakna. Dengan pembelajaran terpadu siswa diharapkan mempunyai kemampuan untuk mengidentifikasi, mengarahkan, menilai dan memanfaatkan informasi yang ada di sekitarnya secara bermakna. Hal ini dapat diperoleh tidak saja melalui pembekalan pengetahuan baru kepada siswa melainkan melalui kesempatan meningkatkan dan menerapkannya dalam berbagai kondisi yang semakin beragam (Rusman, 2013).

Peneliti telah melakukan studi pendahuluan di kelas V MIT Ar-Rifqi Cimekar Bandung, pada saat praktik pengenalan lapangan (PPL) pada bulan September-Desember 2017. Dari sana dapat diperoleh keterangan bahwa aktivitas pembelajaran siswa di sekolah tersebut masih rendah, hal ini dapat diketahui ketika siswa-siswi belajar mata pelajaran IPS pokok bahasan lingkungan bersih dan sehat, dari sana dapat diketahui bahwasannya antusias siswa dalam membaca sebuah teks bacaan ataupun menulis yang berhubungan dengan bahan ajar siswa kurang berpartisipasi aktif dalam proses pembelajaran, lalu terlihat juga pada saat guru mengajukan pertanyaan siswa kurang berpartisipasi dalam menjawab, begitupun terlihat pada saat guru menjelaskan suatu bahan ajar siswa kurang cakap dalam menyimak dan mendengarkan apa yang disampaikan, dan juga pada saat diskusi kelompok siswa kurang berpartisipasi aktif dalam proses berjalannya diskusi di kelas, begitupun pada saat guru memberikan kesempatan pada siswa untuk bertanya, memberi tanggapan, ataupun mengajukan pendapat saat pembelajaran akan berakhir, siswa-siswi kurang menanggapi perintah guru dan menunjukan sikap acuh. 
Terkait perihal di atas, pembelajaran IPS Terpadu adalah satu di antara mata pelajaran yang proses penyampaiannya lebih mudah dengan penggunaan metode ajar karena bahan ajar yang abstrak seakan-akan bisa terlihat nyata (Suhada, 2014). Dengan demikian penelitian ini menggunakan metode pembelajaran Kooperatif Learning tipe Struktur Kontroversi Akademik tentang IPS terpadu

Metode Struktur Kontroversi Akademik merupakan strategi yang dapat diterapkan oleh guru dalam penyajian topik serta persoalan yang bisa menimbulkan pro-kontra. Debat akan berjalan aktif jika dibentuk kelompok pro dan kontra untuk saling mengemukakan pendapatnya. Banyak kemampuan yang dapat dilatih dalam strategi ini, diantara kemampuan berbicara dan bisa menyampaikan idenya kepada orang lain (Marno, 2008).

Metode Struktur Kontroversi Akademik ini bisa membantu siswa untuk lebih aktif dalam proses kegiatan belajar mengajar, begitupun juga siswa diharuskan untuk berfikir mengenai menyelesaikan suatu persoalan dengan teman kelompoknya sehingga terjalin kerjasama yang baik dan saling bertukar pemikiran untuk menyelesaikan suatu perdebatan dan mengkomunikasikan pada kelompok lain (Silberman, 2016). Begitupun diperkuat dari penelitian Santicola bahwa metode struktur kontroversi akademik memiliki peran positif dalam pembelajaran di sekolah (Santicola, 2014).

Menurut David W. Johnson penemu metode Struktur Kontroversi Akademik dalam (Warsono 2017) metode Struktur Kontroversi Akademik ialah aktivitas yang membicarakan suatu masalah dalam kelompok, adanya situasi yang sulit dalam topik bahan ajar yang menimbulkan perdebatan yang diajukan oleh guru. Struktur Kontroversi Akademik merupakan suatu proses pembelajaran dimana siswa akan menyelidiki dan mendiskusikan satu atau beberapa topik yang kontroversi dalam proses pembelajaran kemudian mengkomunikasikan pada kelompok lain secara sistematis (Tavakoli, 2017). Pasangan pertama bertugas menyepakati atau mendukung, sedangkangkan pasangan berikutnya bertugas menentang konsep yang kontroversial tersebut.

Menurut (Hamdayama, 2015) kelebihan metode pembelajaran debat atau struktur kontroversi akademik ialah bisa membuat siswa lebih meningkatkan pengetahuannya mengenai suatu konsep pembelajaran, membiasakan siswa supaya bersikap kritis dan mengajarkan siswa agar lebih berani mengargumentasikan ide atau gagasanya pada orang lain dalam proses pembelajaran di kelas. Selain itu keuntungan dari teori pembelajaran kooperatif tipe kontroversi akademik menurut O'Donnell \& O'Kelly,dan Johnson adalah siswa dapat mencapai pemahaman yang lebih baik melalui penggunaan metode konflik kognitif (Santicola, 2014). Begitupun penggunaan metode kontroversi akademik yang tepat akan meningkatkan motivasi belajar pada siswa dan membuat siswa fokus dalam proses pembelajaran dan tentunya akan meningkatakan prestasi belajar (Susilo, 2013).

Begitupun menurut (Hamdayama 2015) kekurangan dari metode struktur kontroversi akemik adalah Pada saat siswa menyampaikan suatu gagasan akan terjadi perebutan pendapat dari setiap siswa, lalu terjadi juga perdebatan yang tak kunjung selesai, begitupun siswa yang kurang cakap dalam mengemukakan pendapat akan terasingkan oleh siswa yang pandai berargumen, begitupun kekurangan metode debat ini akan menghabiskan waktu yang cukup lama, dan metode ini diperlukan topik pembahsan yang mudah dimengerti dan harus bisa diperdebatkan oleh siswa, terkadang juga yang menjadi kekurangan dalam metode ini adalalah pembagian siswa dalam kelompok yang tidak merata.

Selain itu Rodgers berpendapat bahwa kekurangan dari model struktur contoversi akademik bahwa siswa harus selalu berinteraksi dengan siswa lainya untuk bertukar pendapat, masalah pada siswa yang kurang berinteraksi akan cenderung diam dan pasif 
(Tavakoli, 2017). Terntunya itu akan menjadi sebuah tantangan bagi seorang pendidik dalam mengajarkan suatu metode ajar cooperative learning tipe Struktur Kontroversi Akademik.

\section{METODOLOGI}

Pendekatan yang digunakan dalam penelitian ini yaitu pendekatan kualitatif. Pendekatan kualitatif merupakan salah satu pendekatan yang mana data ini dapat bertitik tolak dari suatu teori yang telah diakui kebenarannnya dan dapat disusun pada waktu penelitian berlangsung berdasarkan data yang dikumpulkan, serta data kualitatif diperoleh dari hasil lembar observasi dan wawancara (Salahudin, 2015).

Pendekatan kualitatif ini digunakan untuk menentukan hasil dari aktivitas guru dan siswa melalui observasi. Kegiatan observasi ini menghasilkan data berupa kegiatan aktivitas guru dan siswa yang berasal dari lembar observasi. Data yang diperoleh kemudian diolah dengan perhitungan rumus aktivitas guru dan siswa dengan menggunakan pendekatan kualitatif.

Jenis metode yang digunakan adalah Pendidikan tindakan kelas (PTK) merupakan terjemahan Classroom Action Research, yaitu suatu penelitian tindakan yang dilakukan dikelas yang bertujuan untuk mengkaitkan dan memperbaiki proses pembelajaran didalam kelas. Penelitian tindakan kelas merupakan salah satu jenis penelitian yang bersifat praktis Tampubolon (2014:). Dikaitkan praktis karena penelitian ini menyangkut kegiatankegiatan yang dipraktikan oleh guru sehari-hari dalam mengelola program pembelajaran di dalam kelas. Penelitian tindakan kelas dapat diartikan sebagai penelitian yang dilakukan oleh guru di dalam kelasnya sendiri melalui refleksi diri, dengan tujuan untuk memperbaiki kinerjanya sebagai guru, sehingga aktivitas belajar siswa menjadi meningkat.

Penelitian tindakan kelas (PTK) ini, peneliti berorientasi pada penerapan tindakan, dengan tujuan peningkatan mutu atau pemecahan masalah pada subjek yang diteliti dan mengamati tingkat keberhasilan atau akibat tindakannya, kemudian diberikan tindakan lanjutan yang bersifat penyempurnaan tindakan atau penyesuaian dengan kondisi dan situasi sehingga diperoleh hasil yang lebih baik (Salahudin 2015).

Penelitian tindakan Kelas ini sebanyak dua tindakan, dengan setiap siklusnya terdiri dari dua kali pertemuan. Hal ini sama dengan apa yang dikemukakan oleh Susatio bahwasannya penelitian tindakan kelas (PTK) menggunakan dua tindakan, analisis dan refleksi dalam setiap siklusnya berdasarkan hasil observasi yang terekam dalam catatan lapangan dan format- format pengamatan lainnya. Fokus pengamatan diarahkan pada kegiatan guru dan siswa selama pembelajaran di kelas dan perubahan sikap siswa (Susatio, 2013).

Menurut Arikunto (2010) terdapat empat tahapan yang dilalui, yaitu (1) Perencanaan, (2) Pelaksanaan, (3) Pengamatan, (4) Refleksi. Adapun alur siklus pada Penelitian Tindakan Kelas dapat dilihat dari gambar di bawah ini: 


\section{MODEL PENELITIAN TINDAKAN KELAS}

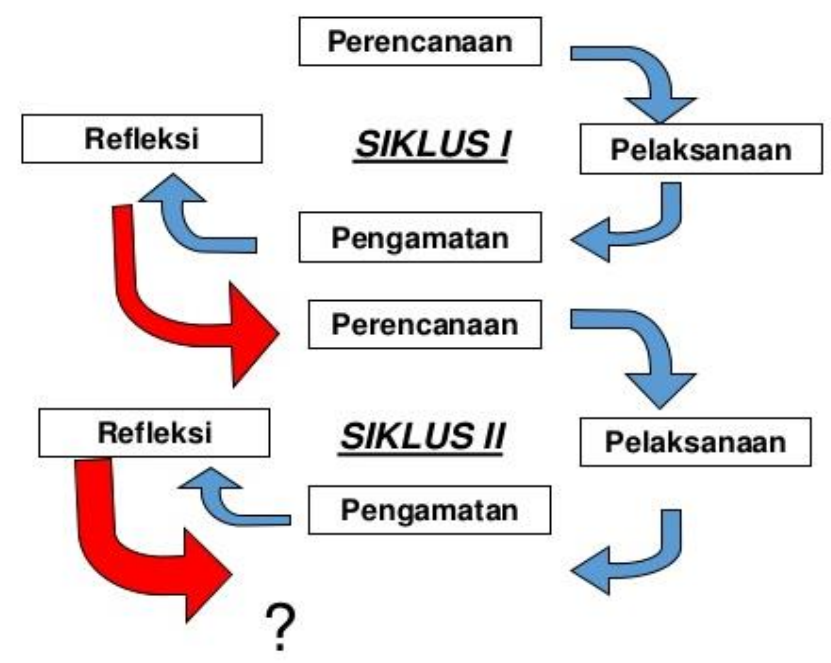

Gambar 1 Siklus PTK

Sumber: Arikunto, 2010

Pada penelitian ini, prosedur yang akan dilakukan secara garis besar meliputi empat tahapan pokok, yaitu : (1) perencanaan ( planning) (2) pelaksanaan (acting), (3) pengamatan (observing) (4) refleksi (reflecting).

Penelitian dilakukan di MIT Ar-Rifqi Kota Bandung yang bertempat di Komplek Bumi Panyileukan Blok K 8 No. 29 RT 03 RW 03 RW 10 Cipadung Kidul Kec. Panyileukan Kota Bandung. Waktu penelitian diperkirakan selama satu bulan, sekitar pertengahan bulan Maret sampai pertengahan bulan April 2018. Alasan peneliti memilih MIT Ar-Rifqi sebagai lokasi penelitian karena ditemukannya masalah pembelajaran yaitu rendahnya aktivitas belajar siswa ketika proses pembelajaran.

Jenis data yang digunakan dalam penelitian ini adalah penelitian data kualitatif dan penelitian data kuantitatif yang mana penelitian ini dapat bertitik tolak dari suatu teori yang telah diakui kebenarannnya dan dapat disusun pada waktu penelitian berlangsung berdasarkan data yang dikumpulkan (Salahudin, 2015). Data kualitatif diperoleh dari hasil lembar observasi siswa dan lembar observasi guru pada saat pembelajaran berlangsung dan wawancara mengenai proses pembelajaran mengenai penerapan metode struktur kontroversi akademik pada saat pembelajaran berlangsung pada siswa kelas $\mathrm{V}$ dan guru kelas V.

Penentuan lokasi didasarkan pada alasan secara akademik permasalahan yang diteliti di MIT Ar-Rifqi, tempat penelitian dipilih berdasarkan temuan pada observasi awal yang mengidentifikasi adanya beberapa permasalahan yang harus mendapatkan pemecahan atau solusi terhadap rendahnya aktivitas belajar siswa. Sedangkan, subjek penelitian ini adalah guru mata pelajaran IPS yaitu peneliti sendiri, siswa kelas V sebanyak 20 siswa pada saat pembelajaran berlangsung dengan penggunaan metode struktur kontroversi akademik, suasana aktivitas pembelajaran dikelas, serta dokumentasi siswa berupa foto kegiatan selama pembelajaran berlangsung.

Teknik pengumpulan data yang digunakan dalam penelitian ini adalah lembar observasi aktivitas guru, siswa dan dokumentasi . Observasi atau pengamatan sebagai alat penilaian banyak digunakan untuk mengukur tingkah laku individu atau proses terjadinya suatu kegiatan atau proses yang dapat diamati, baik dalam situasi sebenarnya maupun 
situasi buatan (Hayati, 2013). Observasi dilakukan untuk mendapatkan data mengenai aktivitas guru dan siswa dikelas peneliti menggunakan cara pengamatan secara langsung melalui lembar observasi siswa dan guru. Pengamatan ini dilakukan pada setiap proses pembelajaran, mulai siklus pertama sampai siklus terakhir oleh observer.

Pedoman observasi aktivitas siswa adalah untuk menilai partisipasi siswa dalam proses pembelajaran. Sedangkan pedoman aktivitas guru berfungsi untuk menilai kemampuan guru dalam penerapan teknik yang diujikan agar membantu meningkatkan aktivitas belajar siswa. Pedoman observasi siswa dan guru tersebut berbentuk format lisan.

Dokumentasi menurut Sugiyono (2014) dokumentasi merupakan catatan peristiwa yang sudah berlalu. Dokumen yang berbentuk tulisan digunakan untuk memperoleh data yang berisi catatan harian berupa daftar kehadiran siswa dan daftar nilai harian siswa pada setiap tindakan. Dokumentasi berusaha mencari data mengenai hal-hal berupa foto-foto kegiatan, catatan, transkip dan sebagainya. Dokumentasi penulis digunakan untuk memperoleh data sebagai pelengkap data-data yang didokumentasikan, diantaranya catatan harian siswa, absen kehadiran siswa, daftar nilai, dan prestasi siswa serta rencana tindakan.

Analisis data observasi diperoleh dari penghitungan hasil rata-rata di setiap siklus, dihitung dan dipaparkan dari analisis lembar observasi siswa. Adapun teknik penghitungan menggunakan rumus :

Rumus

Mean (rata-rata)

$$
\mathrm{M}=\frac{\Sigma \mathrm{X}}{\mathrm{N}}
$$

\section{Keterangan}

$\mathrm{M}=$ Mean (rata-rata)

$\Sigma \mathrm{X}=$ Jumlah skor

$\mathrm{N}=$ Jumlah siswa

Setelah dirata-ratakan, kemudian dipersentasikan ke dalam grafik sederhana. Persentase dihitung dengan persamaan :

$$
\mathrm{NP}=\frac{\mathrm{R}}{\mathrm{SM}} \times 100 \%
$$

Sumber: Zaenal Arifin, 1991)

$\begin{array}{lll}\text { Keterangan } & & \text { Sumber: }(P \\ \mathrm{NP} & = & \text { nilai persen yang dicari atau diharapkan } \\ \mathrm{R} & = & \text { skor mentah yang diperoleh siswa } \\ \mathrm{SM} & = & \text { skor maksimum ideal } \\ 100 \% & = & \text { bilangan tetap }\end{array}$

Tabel 1Pedoman Penilaian Aktivitas Belajar Peserta Didik

$\begin{array}{ccc}\text { Tingkat Penguasaan } & \text { Bobot } & \text { Kategori } \\ 86-100 \% & 4 & \text { Sangat baik } \\ 76-85 \% & 3 & \text { Baik } \\ 60-75 \% & 2 & \text { Cukup } \\ 55-59 \% & 1 & \text { Kurang } \\ \leq 54 \% & 0 & \text { Kurang sekali }\end{array}$

Sumber: Purwanto, 2012 
Analisis data yang digunakan dalam dokumentasi berupa foto aktivitas selama kegiatan belajar berlangsung dalam setiap siklus, untuk memperoleh data yang berisi catatan harian berupa daftar kehadiran siswa, daftar nilai harian siswa dan dokumentasi foto digunakan untuk memaparkan kegiatan pada setiap tindakan saat penelitian berlangsung. Setiap tindakan kemudian dijelaskan pada tahapan bab pembahasan karena kejadian dalam pelaksanaan penelitian merupakan sebuah proses yang tidak terbatas, oleh karena itu diharapkan dokumentasi kegiatan penelitian dapat mengungkap secara empiris dan selanjutnya mampu dijadikan sebagai bukti yang lebih akurat.

\section{HASIL DAN DISKUSI}

Berdasarkan hasil penelitian yang dilakukan dilapangan tentang upaya meningkatkan aktivitas belajar menggunakan metode academic controversy diperoleh data sebagai berikut:

1. Data aktivitas belajar siswa pra siklus

Berdasarkan hasil observasi aktivitas belajar siswa pra siklus maka dapat dijelaskan bahwa aktivitas belajar siswa pada pembelajaran IPS materi perubahan lingkungan aktivitas belajar siswa kurang aktif. Hal ini bisa dilihat dari persentase yang didapat yaitu sebesar 31,2\% dari seluruh rangkaian aktivitas pembelajaran pada pra siklus.

2. Data aktivitas belajar siswa pada siklus I

Berdasarkan hasil observasi aktivitas siswa pada siklus I tindakan pertama dan kedua dengan hasil tindakan pertama sebesar $61 \%$ dan tindakan kedua sebesar $64 \%$ maka dapat dirata-ratakan yaitu $62 \%$ aktivitas siswa terlaksana dalam siklus 1.

Apabila melihat kepada kriteria keterlaksanaan aktivitas pembelajaran, angka $62 \%$ termasuk ke dalam kategori "Aktif”. Berdasarkan rekapitulasi skor aktivitas siswa dalam pembelajaran siklus I. Maka dapat diketahui aktivitas siswa pada pembelajaran IPS tema perubahan lingkungan aktif. Hal ini terlihat dari persentase yang didapat yaitu sebesar $62 \%$ dari seluruh rangkaian aktivitas siswa dalam pembelajaran pada siklus I. Persentase aktivitas siswa tersebut dapat dilihat pada grafik.

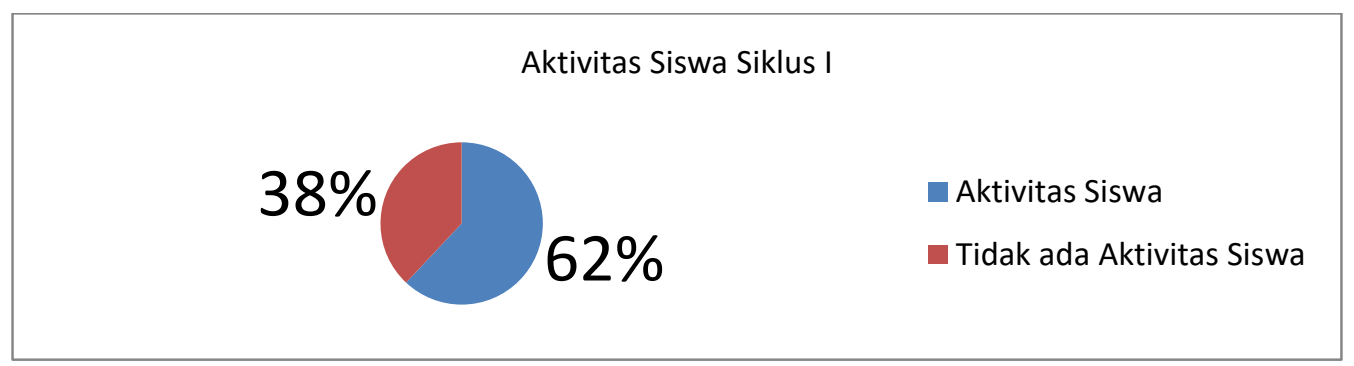

Gambar 2 Persentase Aktivitas Siswa Siklus I

Berdasarkan hasil persentase aktivitas siswa pada siklus 1 dapat disimpulkan bahwa hasil yang diperoleh yaitu $62 \%$ aktivitas siswa terlaksana dalam proses pembelajaran, dan sisanya $38 \%$ aktivitas siswa tidak terlaksana dalam proses pembelajaran.

3. Data aktivitas belajar siswa setelah diterapkan metode Academic Controversy

Berdasarkan hasil observasi aktivitas siswa pada siklus II dengan hasil tindakan pertama sebesar $80 \%$ dan tindakan kedua sebesar $92 \%$ maka dapat dirata-ratakan yaitu $86 \%$ aktivitas siswa terlaksana dalam proses pembelajaran pada siklus II.

Apabila melihat kepada kriteria keterlaksanaan aktivitas pembelajaran, angka 86\% termasuk ke dalam kategori "Sangat Aktif". Berdasarkan rekapitulasi skor aktivitas siswa 
dalam pembelajaran siklus II. Maka dapat diketahui aktivitas siswa pada proses pembelajaran sangat aktif. Hal ini terlihat dari persentase yang didapat yaitu sebesar $86 \%$ dari seluruh rangkaian aktivitas siswa dalam pembelajaran pada siklus II. Persentase aktivitas siswa tersebut dapat dilihat pada grafik di bawah ini.

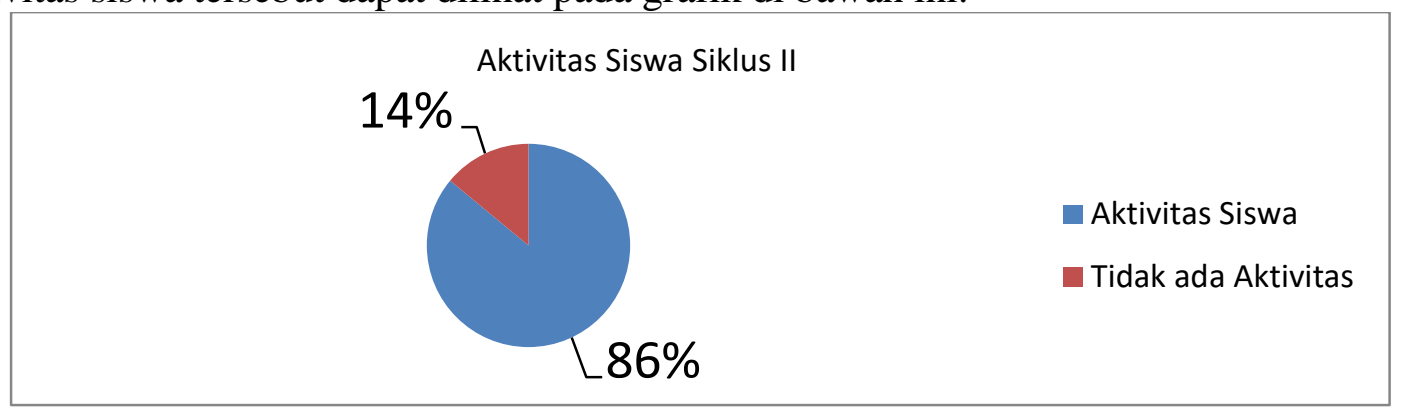

Gambar 3 Persentase Aktivitas Siswa Siklus II

Berdasarkan hasil persentase aktivitas siswa pada siklus 2 dapat disimpulkan bahwa hasil yang diperoleh yaitu $86 \%$ aktivitas siswa terlaksana dalam proses pembelajaran, dan sisanya $14 \%$ aktivitas siswa tidak terlaksana dalam proses pembelajaran pada siklus 2 .

Untuk melihat secara signifikan hasil peningkatan dimulai dari pra siklus, siklus I dan siklus II, berikut dipaparkan secara lebih jelas pada tabel di bawah ini.

Tabel 2 Peningkatan Aktivitas Belajar Siswa

Aktivitas Belajar Siswa

\begin{tabular}{cccccc} 
Keterangan & Pra Siklus & \multicolumn{2}{c}{ Siklus I } & \multicolumn{2}{c}{ Siklus II } \\
& & Tindakan 1 & Tindakan 2 & Tindakan 1 & Tindakan 2 \\
Skor & 20 & 39 & 41 & 51 & 59 \\
Jumlah & 31,2 & 61 & 64 & 80 & 92 \\
Presentase & $31,2 \%$ & $61 \%$ & $64 \%$ & $80 \%$ & $92 \%$
\end{tabular}

Berdasarkan tabel hasil aktivitas belajar siswa dengan menggunakan model Cooperative Learning Tipe Struktur Kontroversi Akademik (Academic Controversy) pada pembelajaran IPS tema perubahan lingkungan mengalami peningkatan dari setiap tindakan, peningkatannya meliputi pra siklus $31,2 \%$ (kurang), siklus I tindakan pertama $61 \%$ (cukup), siklus I tindakan kedua 64\% (cukup) dan siklus II tindakan pertama 80\% (sangat aktif), siklus II tindakan kedua 92\% (sangat aktif). Adapun untuk memperjelas perbandingan hasil observasi pada setiap siklus dapat dilihat pada grafik berikut:

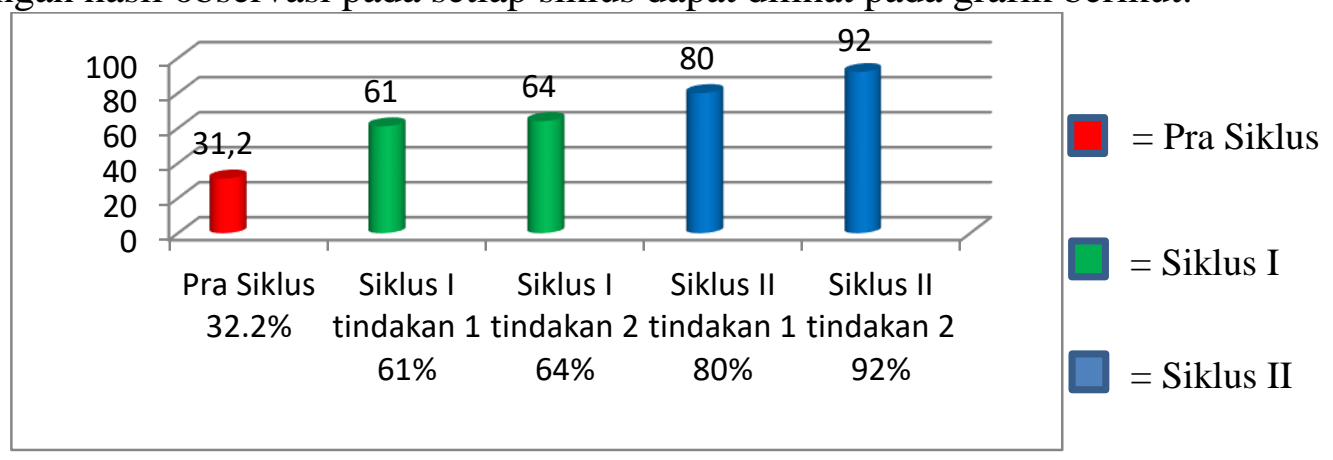

Grafik 3 Peningkatan Aktivitas Belajar Siswa Setiap Siklus 
Aktivitas belajar siswa dalam mengikuti pembelajaran IPS dengan menggunakan model Cooperative Learning Tipe Struktur Kontroversi Akademik (Academic Controversy) pada setiap siklus mengalami peningkatan, seperti pada grafik di atas.

4. Aktivitas Debat Pro dan Kontra pada Siklus I dan II

Adapun hasil observasi aktivitas debat pro dan kontra selama kegiatan pembelajaran pada siklus I tindakan pertama dan siklus I tindakan kedua, dilanjutkan pada siklus II tindakan pertama dan siklus II tindakan kedua dapat dilihat pada tabel berikut:

\begin{tabular}{ccccc} 
& \multicolumn{5}{c}{ Tabel 3 Peningkatan Aktivitas Debat Pro dan Kontra } \\
Keterangan & \multicolumn{4}{c}{ Aktivitas Debat Pro dan Kontra } \\
& Tindakan 1 & Tiklus I & Tindakan 2 & Siklus II \\
Jumlah & 1.310 & 1.490 & 1.615 & Tindakan 2 \\
Rata-rata & 65 & 74,5 & 81 & 1.650 \\
presentase & $65 \%$ & $74,5 \%$ & $81 \%$ & 83 \\
& & & & $83 \%$
\end{tabular}

Hasil aktivitas debat pro dan kontra dengan menggunakan model Cooperative Learning Tipe Struktur Kontroversi Akademik (Academic Controversy) mengalami peningkatan dari setiap tindakan, peningkatannya meliputi siklus I tindakan pertama $65 \%$ (cukup aktif), siklus I tindakan kedua 74,5\% (cukup aktif) dan siklus II tindakan pertama $80 \%$ (baik), siklus II tindakan kedua 92\% (sangat aktif). Adapun untuk memperjelas perbandingan hasil observasi pada setiap siklus dapat dilihat pada grafik berikut.

Grafik 4 Peningkatan Aktivitas Debat Pro dan Kontra

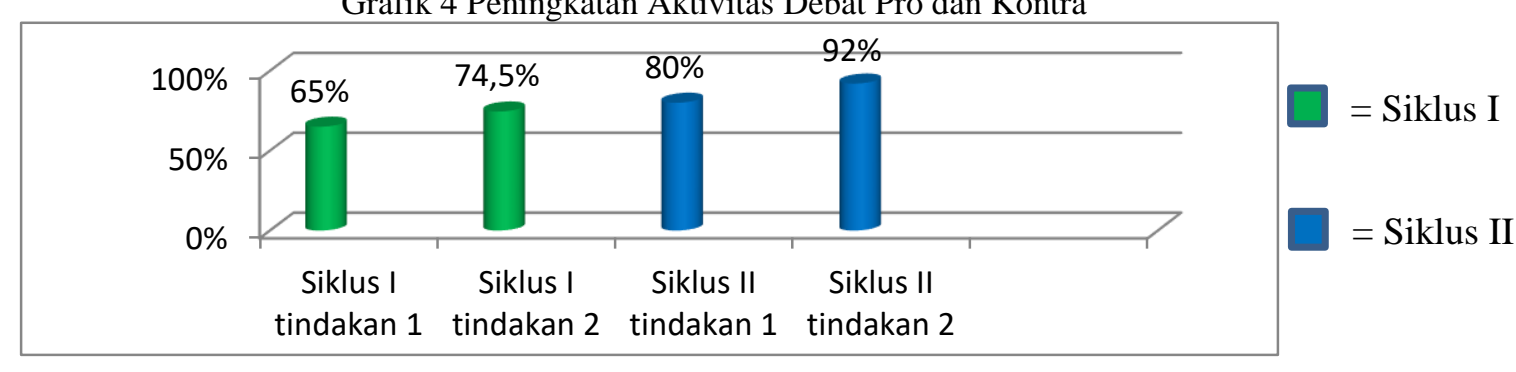

Aktivitas debat pro dan kontra dalam pembelajaran IPS dengan menggunakan model Cooperative Learning Tipe Struktur Kontroversi Akademik (Academic Controversy) pada setiap siklus mengalami peningkatan, seperti pada grafik di atas. Maka dengan adanya peningkatan aktivitas debat pro dan kontra pada setiap siklus berarti model Cooperative Learning Tipe Struktur Kontroversi Akademik (Academic Controversy) terbukti dapat meningkatkan aktivitas belajar siswa.

\section{KESIMPULAN}

Berdasarkan hasil Penelitian Tindakan Kelas dengan menerapkan model Cooperative Learning Tipe Struktur Kontroversi Akademik (Academic Controversy), maka dapat diambil kesimpulan bahwa aktivitas belajar siswa sebelum menggunakan model Cooperative Learning Tipe Struktur Kontroversi Akademik (Academic Controversy) hanya mencapai 31,2\% dengan kategori kurang aktif. Hal ini dikarenakan siswa kurang antusias dalam pembelajaran, sehingga pembelajaran menjadi jenuh dan kurang aktif. Penerapan model Cooperative Learning Tipe Struktur Kontroversi Akademik (Academic Controversy) tergolong aktif. Aktivitas siswa pada siklus I tindakan (pertama) diperoleh data yaitu $61 \%$ sedangkan pada tindakan (kedua) diperoleh data $64 \%$ dapat diketahui rata- 
rata aktivitas siswa pada siklus I yaitu 62\%. Sedangkan aktivitas siswa pada siklus II tindakan (pertama) diperoleh data yaitu $80 \%$ dan pada tindakan (kedua) diperoleh data yaitu $92 \%$ dapat diambil kesimpulan rata-rata aktivitas siswa pada siklus II yaitu $86 \%$ dengan kategori (sangat aktif). Dari data yang diperoleh dapat diambil kesimpulan penerapan metode struktur kontroversi akadamik dapat meningkatkan aktivitas belajar dari $62 \%$ pada siklus I menjadi $86 \%$ pada siklus II. Sedangkan aktivitas belajar siswa setelah menggunakan model Cooperative Learning Tipe Struktur Kontroversi Akademik (Academic Controversy) mengalami peningkatan, yaitu pada siklus I tindakan (pertama) aktivitas siswa sebesar 61\% sedangkan pada tindakan (kedua) aktivitas siswa sebesar 64\% dengan rata-rata aktivitas siswa pada siklus I sebesar 62\% dengan kategori cukup aktif. Dan pada siklus II tindakan (pertama) aktivitas siswa yaitu $80 \%$ sedangkan tindakan (kedua) 92\% dengan rata-rata aktivitas siswa pada siklus II sebesar 86\% dengan kategori sangat aktif. Maka dengan adanya peningkatan aktivitas belajar siswa pada setiap siklus berarti model Cooperative Learning Tipe Struktur Kontroversi Akademik (Academic Controversy) terbukti dapat meningkatkan aktivitas belajar siswa. Sehingga hipotesis dalam penelitian ini dapat diterima.

\section{DAFTAR PUSTAKA}

Arifin, Zainal. (1991). Evaluasi Instruksional (Prinsip-Teknik-Prosedur). Bandung: PT Remaja Rosdakarya

Arikunto, Suharsimi. (2010). Prosedur Penelitian (Suatu Pendekatan Praktik). Jakarta: Rineka Cipta

Bacon, D. R. (2016). Reporting Actual and Perceived Student Learning in Education Research. Journal of Marketing Education, 38(1), 3-6. https://doi.org/10.1177/0273475316636732

Hamdayana. (2015). Model dan Metode Pembelajaran Kreatif dan Berkarakter, Bogor: Ghalia Indonesia

Hayati, Tuti. (2013). Evaluasi Pembelajaran, Bandung: Insan Mandiri

Marno, Idris. (2008). Strategi dan metode pengajaran, jogjakarta: Ar-Ruzz Media.

Melvin, Silberman. (2016). Active Learning. Bandung: NUANSA

Purwanto, Ngalim. (2012). Prinsip-prinsip dan Teknis Evaluasi Pembelajaran. Bandung: PT Remaja Rosdakarya

Rusman, (2013). Model-model Pembelajaran, 229

Salahudin, Anas. (2015). Penelitian Tindakan kelas. Bandung: CV Pustaka Setia.

Santicola, C. F. (2014). Academic Controversy in Macroeconomics: An Active and Collaborative Method to Increase Student Learning. American Journal of Business Education, 8(3), 177-184. Retrieved from http://eric.ed.gov/?q=cooperative+learning+techniques\&pr $=0 \mathrm{n} \& \mathrm{ft}=\mathrm{on} \& \mathrm{ff} 1=\mathrm{dty}$ Since 2011\&ff2=eduHigher+Education\&id=EJ1069013

Sugiyono. (2014). Metode Penelitian Kuantitatif dan Kualitatif dan $R \& D$. Bandung: Penerbit Alpabeta.

Suhada, Idad. (2014) Pengembangan Pendiidkan IPS di MI. Bandung: Yrama widya

Susilo, A. (2013). Academic Controversy Model As An Alternative Strategy For Teaching Speaking At University Level. Cendekia, 11(2), 285-297.

Tampubolon, Saur. (2014). Penelitian Tindakan Kelas: Sebagai Pengembangan Profesi Pendidik dan Keilmuan. Jakarta: Penerbit Erlangga

Tavakoli, R. (2017). The Effect of Structured Academic Controversy on English Proficiency Level within Communicative Language Teaching Context, 8(2), 349-354. 